\title{
"THE TASK OF HEARING WHAT HAS ALREADY BEEN SAID": HISTORY AND NATIVE AMERICAN LEGAL CLAIMS
}

\author{
By Aviam Soifer*
}

The words of the Ba'al Shem Tov inscribed at Yad Vashem, the Holocaust Memorial in Jerusalem, remind us that "The key to redemption is remembrance". ${ }^{2}$ Remembrance itself is a mitzvah, a sacred obligation, anchored in repeated scriptural injunctions. Children who become bar and bat mitzvot at age thirteen may learn that the verb zakhor (remember) occurs in the Bible $13 \times 13$ or 169 times, (and they are taught that this numerology is significant). The word appears "usually with either Israel or God as the subject, for memory is incumbent upon both". ${ }^{3}$ Yet there are crucial differences - as well as significant overlaps - between memory of the past; meaning in history; and historical inquiry largely concerned with accurate chronology and concrete facts. Too often, the term "history" is used to blur or ignore these differences.

To illuminate this point, this essay considers several recent invoca-

I The phrase quoted is a subheading from Robert A. Williams, Jr., "Documents of Barbarism: The Contemporary Legacy of European Racism and Colonialism in the Narrative Traditions of Federal Indian Law", 31 Ariz. L. Rev. 237, 258 (1989). Using the work of Albert Memmi, a Tunisian Jew who survived a Nazi work camp, Williams offers a powerful taxonomy of racism that he claims is applicable to legal treatment of tribalism and of Native American claims specifically.

* Dean and Professor of Law, Boston College Law School. Many people were remarkably hospitable to me and my family during our last visit to Tel Aviv University, and particularly helpful as I thought about this essay. Among them were: President Yoram Dinstein and Dean Ariel Rosen-Zvi; Professors Natan Lerner, Kenneth Mann, Sasson Samekh, Amos Shapira and Leon Sheleff; and Doctors Karen Alkaly-Gut, Arnon Gutfeld and Haggai Hurvitz. I am also very grateful to the staff of the Israel Yearbook of Human Rights, to Vicki Schlachet, and to my extraordinary research assistants Janet Judge and Brad Steiner.

2 It seems fitting to begin with this quotation, which concluded my discussion of the role of "involuntary groups" in Anglo-American jurisprudence in Aviam Soifer, "On Being Overly Discrete and Insular: Involuntary Groups and the Anglo-American Judicial Tradition", 20 Israel Yearbook on Human Rights 243 (1990). This essay is a continuation of that exploration.

3 Y. H. Yerushalmi, Zakhor: Jewish History and Jewish Memory 5 (1989). 
tions of history by American judges. It does so in the context of Native American legal claims, ${ }^{4}$ but its point about the demands and abuse of history has broader implications. My argument is that each of three distinct judicial approaches to the past exemplified by these decisions is seriously flawed. Taken together, however, these cases underscore how claims purportedly derived from history can become a powerful whipsaw. As we will see, these recent decisions employ history inconsistently, yet with devastating effectiveness, against Indian claims. They demonstrate how commonplace it is for judges to make claims based on history, while blithely remaining blind to the crucial understandings at the confluence of memory, meaning and historical accuracy.

Judicial lapses in remembrance are hardly trivial. Indeed, such flaws extend far beyond specific results - the bottom line - in the three decisions at issue. None of these cases is in itself of great import. Even the two United States Supreme Court decisions appear almost insignificant in their specific outcomes. But the horrors of this century show that even if "[r]esponsibility for a burdened past can justifiably become less preoccupying as other experiences are added to the national legacy", it remains inestimably important to understand that "like the half-life of radioactive material, there is no point at which responsibility simply goes away". 5

Decisions that undermine Native American legal claims are hardly unusual in the United States' history. Yet these three very recent decisions vividly indicate some of the routine ways in which judges have followed soldiers and settlers in a rush to establish a new "reality on the ground", a legal fait accompli that somehow is said to legitimize unburdening the American landscape of its most longstanding population. In the modern (or postmodern) world, measured judicial words do immeasurable violence to what was and what could be. It is still a remarkable, bitter irony that at the core of each of these judicial opinions lies the assertion that history itself compels the extirpation of memory, meaning and precision about the United States' past burdens.

That irony is equalled, if not exceeded, when we begin to discern the techniques contemporary judges employ to devalue and ultimately

4 I generally use the term "Native American", but also employ "Indian" when that seems to make historical or stylistic sense. The claims discussed involve quite different legal matters. They concern, respectively, government benefits, land claims and sovereignty over hunting and fishing rights.

5 C. S. Maier, The Unmasterable Past: History, Holocaust, and German National Identity 15 (1988). 
dismiss the weight of words themselves. Justice Antonin Scalia, now joined by his acolyte, Justice Clarence Thomas, likes to insist that there must be strict judicial fidelity to legal texts. Yet when we turn to majority opinions written by Scalia J. and Thomas J., we see they simply wave away directly relevant texts and language. As part of the Court's unseemly gallop toward more limited governmental responsibility in respect to Native Americans - or in respect to anyone else, for that matter - these Justices resort to the spirit of abstract concepts and to dubious claims of implicit past understandings.

In a strange kind of symbiosis, the Justices then assign responsibility to history for the outcomes they struggle to reach. They use history to trump texts that quite clearly seem to point in the opposite direction. In the third decision, the Vermont Supreme Court similarly invokes history. This version is an even more abstract concept of implicit, cumulative, and undifferentiated encumbering by the past. All three decisions clearly invoke "history". In all three, however, memory is made irrelevant, meaning is stretched past the breaking point, and accuracy about the past is made to seem entirely irrelevant. Unfortunately, these three decisions exemplify the way in which many contemporary American judges seek a unified, generalized vision called History. There seems to be a compulsion to find some fixed, "correct" rule for interpreting language. That propensity is particularly striking in the context of legal claims by Native Americans.

The first decision pays homage to Abstract History; the second to Cumulative History; and the last to Implicit History. All are entirely unsatisfactory. Moreover, in their purported quest for the compulsion of history, the Justices play fast and loose with legal language and with its historical meaning. This contrasts sharply with the Native American perspective. Among Native Americans, as Bruce Swann described it, "Reality is not 'controlled', no matter on how high a plane. We would do better to talk of reciprocity, balancing, right acting and right telling in the interests of equilibrium". ${ }^{6}$ It is always dangerous to make sweeping generalizations, of course, but at a minimum, reciprocity, balancing, right acting and right telling might serve well as judicial goals. It is noteworthy that these qualities are sorely lacking in recent judicial responses to the claims of Native Americans. ed., 1983) Swann quotes Lame Deer's explanation: "We Indians live in a world of symbols and images where the spiritual and the commonplace are one". Ibid., xii, quoting John Fire/Lame Deer and Richard Erdoes, Lame Deer, Seeker of Visions 101 (1972). 


\section{VILLAGE OF NOATAK: HISTORY AS AN ABSTRACTION}

Judicial myopia about history in the context of Native American rights is itself a tragic old story. ${ }^{7}$ The recent case of Blatchford $v$. Native Village of Noatak ${ }^{8}$ proves, however, that a story need not be old to be tragic, comic, or both. In this seemingly dry, technical decision about the sovereign immunity of state governments, Native American tribal identity became entangled in the loose ends of one of the most abstract and convoluted topics in American constitutional law. In holding that a Native village could not sue Alaska, Justice Scalia's majority opinion began by conceding that "Indian tribes are sovereigns". ${ }^{9}$ Justice Scalia had to admit that the Court was not relying on the text of the Eleventh Amendment, but rather on "the presupposition of our constitutional structure which [the Eleventh Amendment] confirms". ${ }^{10}$ (This reliance on untethered structural presuppositions is striking in itself, but even more so because it emerged from the word processor of a Justice who insistently claims to be a strict textualist.) Yet our concern is not with a mystical form of Eleventh Amendment doctrine. What is significant about Native Village of Noatak is how the Court hacked through a basic historical riddle: the Gordian knot of the legal status of Native American tribes.

From the decisions of Chief Justice John Marshall through the Court's most recent precedents, the sovereignty of tribes in North America has been anomalous, inconsistent, and remarkably malleable. Pronouncements on the subject by all the branches of the federal government, and by both federal and state courts, have fluctuated with

7 See generally M. Ball, "Constitution, Court, Indian Tribes", [1987] Am. B. Found. Res. J. 3; R. Williams, Jr., The American Indian in Western Legal Thought: The Discourses of Conquest (1990); R. Strickland, "Dances with Lawyers: Wolves, Judges, and Other Medicine Men”, 69 Tex. L. Rev. 995 (1991).

8111 S. Ct. 2578 (1991). Justice Scalia wrote for the majority and Justice Blackmun dissented, joined by Justices Marshall and Stevens.

9 Ibid., 2581.

10 The Eleventh Amendment states: "The Judicial power of the United States shall not be construed to extend to any suit in law and equity, commenced or prosecuted against one of the United States by Citizens of another State, or by Citizens or Subjects of any Foreign State". For the remarkably complicated history of the amendment, see J. Orth, The Judicial Power of the United States: The Eleventh Amendment in American History (1987). That Scalia J. and his fellow textualists practice a peculiar and an inconsistent brand of originalism is obvious to any reader of the Court's opinions, but the point is captured succinctly in G. Kannar, "The Legal Catechism of Antonin Scalia", 99 Yale L.J. 1297 (1990); G. Reynolds, "Penumbral Reasoning on the Right", 140 U. Pa. L. Rev. 1333 (1992). 
changing demands made by the majority culture. ${ }^{11}$ Today, however, it is allegedly clear again that surviving Native American tribes did retain their sovereignty; tribal self-determination is again repeatedly said to be an overriding value. ${ }^{12}$

The puzzle presented in Noatak, therefore, was whether renewed legal sensitivity about tribal sovereignty involves recognition of sovereignty akin to that of foreign States, or sovereignty that is analogous to that of the fifty states within the federal union. This categorization was crucial: on the one hand, Eleventh Amendment doctrine shields states within the United States from suit by foreign sovereigns. On the other hand, any state may sue another state without confronting an Eleventh Amendment barrier. ${ }^{13}$ This suit came to the Court from as far away as possible - the Native Village of Noatak is located on the Bering Strait - and the Justices got nowhere near either the practical realities of the case or any relevant history. Centuries of development, and the Court's own "grandaddy" decisions about tribal status, simply landed in the Justices' conceptualist dustbin.

The suit arose when Alaska reneged on a 1980 Statute that granted every Native Village $\$ 25,000$. On the advice of Alaska's Attorney General, however, the legislature later expanded the recipient class, thereby diluting the share of each Native Village, so that Noatak never received its full initial allotment. ${ }^{14}$ The case presented an array of

11 Ball, supra note 7, provides a wonderfully clear and convincing demonstration of inconsistencies and obtuseness within the "shabby tales composed by the Supreme Court" as the Justices repeatedly have manipulated legal doctrine to reassert the apparent paradox that "the law is that might is the basis of federal power over Indian nations". [1987] Am. B. Found. Res. J. 139, 137.

12 See generally N. J. Newton, "Federal Power Over Indians: its Sources, Scope and Limitations", 132 U. Pa. L. Rev. 195 (1984). The Court celebrated selfdetermination in Oklahoma Tax Comm'n v. Citizen Band Potawatomi Indian Tribe of Oklahoma, 498 U.S. 505, 510 (1991), for example, quoting California v. Cabazon Band of Mission Indians, 480 U.S. 202, 216 (1987): "These Acts reflect Congress' desire to promote 'the goal of Indian self-government, including its "overriding goal" of encouraging tribal self-sufficiency and economic development'."

13 Compare Monaco v. Mississippi, 292 U.S. 313 (1934) with South Dakota v. North Carolina, 192 U.S. 286 (1904). For the current doctrine and background of the legal tangle surrounding the "anachronistic fiction" of sovereign immunity, see Oklahoma Tax Comm'n, 498 U.S. at 514 (Stevens, J., concurring); V. Jackson, "Jackson, The Supreme Court, the Eleventh Amendment, and State Sovereign Immunity", 98 Yale L.J. 1 (1988); J. Orth, supra note 10.

14 Noatak was joined by two other tribal entities in its suit. The state Attorney General had advised that the 1980 Statute, in specifying Native Villages for beneficial treatment, violated equal protection. Though Alaska has run into equal protection difficulties in attempts to distribute some of the bounty from the oil pipeline to 
complicated jurisdictional issues, but the majority answered with a simple, sweeping, surprising assertion: Native American tribes are like foreign nations. Such tribes are Native and American; they are under the plenary power and alleged protection of the federal government; and their members are all citizens of the United States, but the tribe as a tribe is more like Monaco than Montana.

What appealed to Scalia J. and his colleagues, of course, was that the Court's stark choice immunized states against tribal claims. The Court's holding about tribal identity was anything but the product of enlightened revisionist history. Rather, Scalia J. offered only a pseudo-formalistic choice, which he purportedly premised on the original intent of the constitutional framers: "Just as in Monaco with regard to foreign sovereigns, so also here with regard to Indian tribes, there is no compelling evidence that the Founders thought such a surrender [of immunity] inherent in the constitutional compact." But this is remarkably abstract metaphysics. There can be no "compelling evidence" about an issue no one could have imagined at the time.

As Judge John T. Noonan, Jr. held for the lower court in the case, Indian tribes clearly were treated as separate sovereigns long before 1789. They could be found in every original state and relations with them were sensitive and dangerous. Moreover, when a political crisis arose over Georgia's defiance of the Court in the context of the Cherokee Removal during Andrew Jackson's presidency, Chief Justice John Marshall explicitly rejected the idea that tribes were foreign states. ${ }^{15}$ It is therefore deeply ironic that the Court in Noatak simply

citizens, on the basis of their relative longevity within the state (Zobel v. Williams, 457 U.S. 55 (1982)), the Attorney General's opinion here seems dubious at best. It would not have been difficult, for example, to prove through the totality of circumstances the kind of past discrimination needed to defend the statutory plan if any plaintiff actually had been able to overcome jurisdictional difficulties and wished to launch an equal protection attack.

At the most basic level, the treatment of Alaska's Native Peoples who had welcomed white settlers, as directly analogous to "conquered" tribes in the "lower 48 " states flies in the face of history, despite the lumping together of all Native Americans for purposes of federal government control upheld in Tee-Hit-Ton Indians v. United States, 348 U.S. 272 (1955). Moreover, recently the Court repeatedly has upheld differential treatment of Native Americans quite readily, arguing that such classifications are political, not racial, and therefore need only be rationally related to some acceptable governmental purpose. See, e.g., Morton v. Mancari, 417 U.S. 535 (1974); Washington v. Yakima Indian Nation, 439 U.S. 463 (1979).

15 Cherokee Nation v. Georgia, 30 U.S. (5 Pet.) 1, 17-18 (1831). Marshall specifically held that an Indian tribe might be a nation, but that a tribe "is not a foreign state, in the sense of the constitution". Ibid. In this decision, and again in Worcester 
waded into the flood of legal developments over several centuries, in which Indian tribes had been tragically sui generis, and tried to float clear on the flimsy assumption that the relevant inquiry is simply the relative role of the states, foreign nations, and tribes in the Constitutional Convention. According to Scalia J., it is plausible to imagine that the states surrendered sovereign immunity on a theory of mutuality in 1789 , but " $[t]$ here is no such mutuality with either foreign sovereigns or Indian tribes". ${ }^{16}$ Ergo, according to Scalia J., Indian tribes are like foreign nations.

At first glance, the contention that tribal sovereignty is analogous to that of foreign nations may seem a great victory for tribal identity. If it were taken seriously and followed in other contexts, it would have important unanticipated implications, for example, in the realms of international law and human rights guarantees. The analogy to foreign nations also serves to underscore a whole series of basic contradictions in the legal status of Native Americans. Within the logic of Noatak, for example, they have had a unique form of dual citizenship thrust upon them. As we shall see, however, the Court's approach in Noatak has actually been but one in a series of extremely statist decisions that have emerged recently in the Court's treatment of rights claimed by Native Americans, either as individuals or as members of groups. ${ }^{17}$

v. Georgia, 31 U.S. (6 Pet.) 515 (1832), Marshall emphasized the relationship between the federal government and the Indian tribes. He did so directly against claims of state sovereignty that Georgia had vigorously pursued to the point of creating a national crisis. Marshall's approach as well as his language cannot be reconciled with that of the Noatak Court's embrace of Alaska's state sovereign immunity claims. Instead, Marshall constructed the "dependent domestic nations" categorization of the tribal relationship to the federal government that has dominated, and haunted, Indian law ever since. For a careful study of the background of the Georgia cases, see J. Burke, "The Cherokee Cases: A Study in Law, Politics, and Morality", 21 Stan. L. Rev. 500 (1969).

$16111 \mathrm{~S}$. Ct. at 4805 . The specific state sovereign immunity issue had been discussed earlier only in scattered dicta, largely because the prevalent theory was that the federal government had plenary power over the tribes, including the right and the duty to sue states on their behalf, thus overcoming any Eleventh Amendment barrier. A 1966 statutory change explicitly altered federal court jurisdiction to give tribes the ability to sue by themselves, but the Court in Noatak held that Congress had not been adequately explicit to lift the states' Eleventh Amendment barrier.

17 When Native American religious claims were at stake, for example, Scalia J. again wrote for the Court, purporting to recognize the "relative disadvantage" of minority religious practices. Yet he relegated such religious claims exclusively to protection through the political process, proclaiming this to be the "unavoidable consequence of democratic government". Employment Division, Department of Human Resources v. Smith, 494 U.S. 872, 890 (1990). 
The Court's belated rediscovery of tribal sovereignty, deemed akin to foreign sovereignty in Noatak, may be merely a stepping stone to further erosion of the legal claims of Native Americans, who are thus doubly alienated. ${ }^{18}$

Even when recognizing tribal authority the Justices also have reemphasized Congress's plenary power over tribes. ${ }^{19}$ To be sure, it is not easy to classify tribal groups or to categorize the range of their authority. As a legal entity, the tribe has not been respected as "a distinct political society separated from others, capable of managing its own affairs and governing itself" 20 since the days of John Marshall. Even Marshall's idea of a "dependent domestic nation" marked an unwieldy, ambiguous compromise. But if ever freedom of association should have constitutional clout, it ought to be in cases brought by remaining Native American tribes that assert tribal rights. ${ }^{21}$ Yet in Village of Noatak, the Court raced high enough up the ladder of legal abstraction to ignore centuries of history. From that height, it was relatively easy to proclaim

See U.S. v. Alvarez-Nachain, 112 S. Ct. 2188 (1992) (foreign citizens not entitled to protection from kidnapping by federal government); V. Deloria, Jr., "Laws Founded in Justice and Humanity: Reflections on the Content and Character of American Indian Law", 21 Ariz. L. Rev. 202 (1989); V. Deloria, Jr. and C. M. Lytle, The Nations Within: The Past And Future of American Indian Sovereignty (1984).

19 See, e.g., Oklahoma Tax Comm'n v. Citizen Band Potawatomi Indian Tribe of Oklahoma, 498 U.S. 505 (1991) (unanimous decision holding that a state may not tax tribal members but, despite longstanding practice, may prospectively tax sales by tribal members to non-members); Duro v. Reina, 495 U.S. 676, 684 (1990) (holding that "the inherent sovereignty of the Indian tribes does not extend to criminal jurisdiction over non-Indians who commit crimes on the reservation"); Santa Clara Pueblo v. Martinez, 436 U.S. 49 (1978) (rejecting individual sex discrimination claim against tribe on jurisdictional ground, holding that Indian Civil Rights Act of 1968 protects tribal sovereignty, but emphasizing Congress's plenary power to override tribal authority if it sees fit). Ironically, in Hodel v. Irving, 481 U.S. 704, 718 (1987), the Court unanimously held that Congress's plenary power did not extend to a good faith effort to deal with a serious, intractable problem - the "extreme fractionation of Indian lands". Although the Court conceded that the congressional plan would benefit all members of the tribes, and that the fractionation problem was a product of the "disastrous" federal allotment policy and would be compounded over time, the Justices determined that the right of individual property holders to pass on even de minimis property holdings was so vital as to invalidate the statute on constitutional grounds.

21 I make an extended argument for redefining and recognizing the importance of such a right in a book I am finishing, which has the working title, Keeping Company: Groups In American Law and Letters (forthcoming). 
Native American tribes to be akin to foreign nations without thinking much about possible implications. ${ }^{22}$

\section{STATE V. ELLIOTT: HISTORY AS CUMULATIVE}

Just as formalistic manipulation of categories can be used to defeat tribal legal claims, so can purportedly hard-boiled, contemporary policy judgments. The Vermont Supreme Court, for example, recently denied the aboriginal rights of Abenaki Indians to fish in the streams of their ancestral homelands without state licenses. ${ }^{23}$ The case arose when Native Americans staged a "fish-in" demonstration. The defendants were members of a group of 36 people whose defense against charges of fishing without a license invoked "aboriginal rights", premised on their membership in a viable tribe that had existed from "time immemorial" and that had never ceded its land. ${ }^{24}$

The Vermont Supreme Court succinctly and unanimously rejected the Native American claims. The core of Justice Morse's opinion for the Court was that the Indian claims had been voided by "the increasing weight of history". ${ }^{25}$ As the Court rejected a trial court decision that had dismissed the criminal charges against the Abenaki, the Justices maintained that it simply did not matter that the Abenaki had never ceded their claims by treaty. The Court held that the extinguishing of Native American claims occurred, not through any discrete events, but rather via "the cumulative effect of many historical events". ${ }^{26}$

The cumulative events the Court relied upon involved the period preceding Vermont's statehood, which the Court conceded was such "a confusing era" that the Court refused to decide whether or not the government of Vermont did or did not enjoy legal sovereignty over

22 Part of the problem, of course, is that there may not be any implications in a Court that seems little concerned about consistency even within contemporary decisions. In County of Oneida v. Oneida Indian Nation, 470 U.S. 226, 249 (1985), for example, the Court simply proclaimed that tribes are not akin to foreign nations for purposes of invoking the political question doctrine. See generally D. C. Williams, "The Borders of the Equal Protection Clause: Indians as Peoples", 38 U.C.L.A. L. Rev. 759 (1991) and a response by C. Goldberg-Ambrose, and Williams' reply, at 39 U.C.L.A. L. Rev. 169 and 191 (1991). State of Vermont v. Elliott, 616 A. 2d 210 (1992).

24 Under Vermont law, there is an exception to fishing license requirements for persons who fish on their own property. Ibid., at n.1. Ibid., 218. 
the land in question. ${ }^{27}$ Nonetheless, the alchemy of teleological faith transformed old wrongs. Progress, or at least a long line of dubious white land grabs and unsubstantiated legal maneuverings, simply trumped clear, longstanding aboriginal rights. ${ }^{28}$ Moreover, specific attention to history might undercut the basic ideal of treating everyone the same. As the local State's Attorney said in celebration of the decision: "We think this affirms our position all along ... that all Vermonters are equal before the law". ${ }^{29}$

\section{SOUTH DAKOTA V. BOURLAND: HISTORY AS IMPLICIT}

The United States government and the Sioux Nation signed the Fort Laramie Treaty in 1868, their second effort to end the Powder River War that began when the US Army came to the aid of settlers who had claimed sovereignty over the Great Plains. Under the 1868 Treaty, the Sioux agreed to remain within the "Great Sioux Reservation", some 26 million acres "set apart for absolute and undisturbed use and occupation" by the Sioux. ${ }^{30}$ The United States also agreed that non-Indians would not "ever be permitted to pass over, settle upon, produced "extensive and meticulous findings and determined that the Abenaki had settled in northwest Vermont by 9300 B.C. and had occupied that area as "an intact tribe" from that date to the present. Ibid., 214. But the Supreme Court decided that voluminous genealogical, ethnological, and archaeological evidence of an unbroken tribal presence faded away before the dubious claims of squatters and adventurers. The Court simply inferred that the early white settlers of Vermont - in the admitted absence of any explicit legal extinguishment of aboriginal title - eliminated Native American claims through the simple expedient of cumulatively wishing to do so.

For anthropological and legal critiques of another attempt to wrestle with a similar, longstanding clash of cultures in a contemporary courtroom, see "Identity in Mashpee", in J. Clifford, The Predicament of Culture: Twentieth-Century Ethnography, Literature, and Art 277 (1988); G. Torres and K. Milun, "Translating Yonnandio by Precedent and Evidence: The Mashpee Indian Case", [1990] Duke L.J. 625.

29 "Vermont Court Says History Voids Land Claims of Abenaki Indians", N.Y. Times, 18 June 1992 , at D23.

3015 Stat. 635 (1868). The treaty forbade further cession of lands, absent formal written approval "by at least three-fourths of all the adult male Indians," Ibid., at Article 12 . Within a decade, however, Congress explicitly broke the 1868 Treaty. In 1877 , Congress formally adopted a purported agreement signed by 10 percent of the Sioux men. In the wake of the ferociously severe winter of 1875-76, the 
or reside in" the Great Sioux Reservation. ${ }^{31}$ By 1889 , however, Congress had decided to remove a great deal of land from the existing reservation and to subdivide the remaining territory into several reservations. ${ }^{32}$ Moreover, by then Congress already had superimposed the allotment policy of the Dawes Act of 1887 that sought explicitly to break up the tribal structure, to transform Indian land into individual fee simple parcels, to establish the federal government as trustee for the bulk of the land, and gradually to permit resale of land to non-Indians. ${ }^{33}$

Over a century ago, nonetheless, even the Supreme Court recognized that it was tragically clear that the "very weakness and helplessness" of the Indians actually came about "due to the course of dealing of the federal government with them". ${ }^{34}$ The Court also emphasized that the federal government owed the Indians a duty of "care and protection". ${ }^{35}$ It followed, said the Court, that "technical rules" ought not to be used against Indian claims; rather, equitable principles and "that larger reason which constitutes the spirit of the law of nations" provided a legal basis to favour the substance of Indian claims, despite technical barriers. ${ }^{36}$

Battle of Little Big Horn and the Indians' subsequent defeat at Wounded Knee, some of the Indians - denied even subsistence rations by official congressional policy and deprived of all their horses and weapons - relinquished their rights to the Black Hills and other land. The 10 per cent who "agreed" also gave up hunting rights in some unceded land in exchange for the rations desperately needed for survival. The bare bones of the legal and social history of this decade is set out in United States v. Sioux Nation of Indians, 448 U.S. 371, 377-81 (1980).

$31 \quad 15$ Stat. 635, 636.

32 Act of March 2, 1889, Ch. 406, 25 Stat. 888. Of those rights guaranteed the Sioux under the 1868 Fort Laramie Treaty, this 1889 Act now guaranteed only those "not in conflict" with the new statute. Sec. 19, 25 Stat. 896.

33 The General Allotment Act of 1887, Ch. 119, 24 Stat. 388, otherwise known as the Dawes Severalty Act, was a reform measure premised on the assumption that Indians in their tribal units lacked what Dawes described as the "selfishness which is at the bottom of civilization", quoted in A. Debo, And Still the Waters Run 21-22 (1940). Its story is told well in D.S. Otis, The Dawes Act and the Allotment of Indian Lands (F. P. Prucha ed., 1973).

34 United States v. Kagama, 118 U.S. 375, 383-84 (1886) (upholding the Major Crimes Act of 1885, removing jurisdiction over seven criminal offences from the tribes).

35 Choctaw Nation v. United States, 119 U.S. 1, 28 (1886). For further details about the legal entanglements of the Choctaw, who had been slave-holders and who aligned themselves with the losing side in the Civil War, see Aviam Soifer, "The Paradox of Paternalism and Laissez-Faire Constitutionalism: United States Supreme Court, 1888-1921", 5 Law and History Rev. 249, 266-68 (1987).

36 119 U.S. at 28. 
James Bradley Thayer, a renowned Brahmin and Harvard Law School professor, described for the educated general readership of the Atlantic Monthly in 1891 a flood of abuses and misconceived efforts to aid Indians, whom he considered "A People Without Law". Thayer argued that now the federal government owed the Indians an affirmative duty. "The mere neglect or refusal to act is itself action", Thayer explained, "and action of the worst kind". ${ }^{37}$ Thayer invoked history to demolish the very notion that neutrality or neglect could constitute fairness in the context of governmental dealings with Indian tribes. He wrote against the vivid backdrop of devastation wrought through past encounters between government officials and the Indians.

When the Supreme Court revisited the Fort Laramie Treaty and its complicated legal aftermath more than a century later, however, history washed away entirely. In South Dakota v. Bourland, ${ }^{38}$ Justice Thomas's majority opinion held that a series of federal Flood Control Acts in the 1940s and 1950s had deprived the Sioux not merely of still more of their trust lands, but also of the power to regulate hunting and fishing by non-Indians within the reservation. The tribe had decided it would no longer allow non-Indians to hunt deer on the sole basis of their South Dakota hunting licenses. Instead, it now sought to regulate the hunt itself, and to do its own licensing of non-Indians on reservation lands taken for flood control purposes by the federal government.

To the Bourland majority, the purpose of the relevant federal legislation - which nowhere even mentioned abrogation of Indian sovereignty over hunting and fishing - was not decisive. It was not even relevant. Instead, Thomas emphasized that "the effect of the transfer is the destruction of pre-existing Indian rights to regulatory control". ${ }^{39}$ This, of course, is circular reasoning. That was not the effect until the Court so legitimized it in this opinion. The Court's logical legerdemain here - its emphasis on effect and its view that Congressional purpose was irrelevant - is even more striking because it contrasted so starkly with the Court's repeated insistence over the past several decades that a demonstration of discriminatory purpose is a necessary prerequisite for proof of an equal protection violation. ${ }^{40}$ Effect will

37 Thayer's two-part article, “A People Without Law", appeared in the October and November, 1891 issues of the Atlantic Monthly at 540 and 676. The quoted passage is at 678 .

381993 U.S. LEXIS 4034 (14 June 1993).

39 Ibid., 25.

40 There has been considerable discussion of this doctrinal development over the past two decades. For a summary of that literature and my own views, see "On Being Overly Discrete and Insular", supra note 2. 
not suffice to prove constitutional discrimination, but it is adequate to remove the jurisdiction of another sovereign based entirely on unwritten, implicit practices.

This is particularly ironic against the backdrop of the Court's concession that "pursuant to its original treaty with the United States, the Cheyenne River Tribe possessed both the greater power to exclude non-Indians from, and arguably the less-included, incidental power to regulate non-Indian use of the lands later taken for the Oahe Dam and Reservoir Project". ${ }^{41}$ That the greater power includes the lesser power is a favourite trope of the conservative wing of the Court. Therefore, such a statement was ominous even when it initially appeared to favour tribal control. The concept quickly was inverted and used against the Sioux. Premising his claim on two shaky recent precedents, Thomas wrote that "when an Indian tribe conveys ownership of its tribal lands to non-Indians, it loses any former right of exclusive use and occupation of the conveyed lands". ${ }^{42}$ Thomas then administered the coup de grace. He proclaimed, "The abrogation of this greater right . . . implies the loss of regulatory jurisdiction over the use of the land by others". ${ }^{43}$

By this logic, there is virtually nothing left of tribal sovereignty. Congress has plenary power, which necessarily implies power to abrogate all tribal powers whenever it wishes. And, according to this bizarre syllogism, the tribe should have understood, many years prior to this judicial proclamation of a radically new doctrine, that it was giving away all lesser tribal power when it yielded to governmental demands for land under the Flood Control Act of 1944.

As if this logic were not faulty enough, the majority soon made its position even less defencible. Congress had reserved limited land-use rights for the tribe. Somehow this protection of tribal rights supported the repeal of all other rights by implication. Thomas put it bluntly: "When Congress reserves limited rights to a tribe or its members, the very presence of such a limited reservation of rights suggests that the Indians would otherwise be treated like the public at large". ${ }^{44}$ This is

$41 \quad 1993$ U.S. LEXIS 4034, at 17.

42 Ibid., 19, relying on Brendale v. Confederated Tribes and Bands of Yakima Nation, 492 U.S. 408 (1989) and Montana v. United States, 450 U.S. 544 (1981). For a devastating critique of the sharply-divided decision in Brendale, and of its relationship to Montana, see J. Singer, "Sovereignty and Property", 86 NW. U.L. Rev. 1 (1991).

431993 U.S. LEXIS at 19. The Court did not reach the question of whether a different result might follow were the government's greater power said to imply the loss of lesser Indian power over "a 'closed' or pristine area" or in other contexts. Ibid., n. 9. 
a striking example of the Power of the Initial (Legal) Presumption. Here the presumption works with devastating effectiveness against any and all tribal claims because it simply assumes that Indians are in no way an historically special group. Although a tribe may be akin to a foreign nation under Noatak, it and its members simply are to be considered "like the public at large", unless Congress explicitly states otherwise as a matter of largess. Thomas gave lip-service only to the standard principle that "statutes are to be construed liberally in favor of the Indians, with ambiguous provisions interpreted to their benefit" ${ }^{45}$

Over 150 years ago, the Court stated that Indian occupancy rights were "as sacred as the fee simple of whites," retain a "right to the lands they occupy, until that right shall be extinguished by a voluntary cession to our government". ${ }^{47}$ But the flamboyant presumptions and spurious logic of contemporary decisions, such as Noatak and Bourland, turn older ideas and precedents upside down. To be sure, the ongoing conquest of Indian lands - and the often brutal collaborative actions by Congress, the Executive, and the courts - hardly heeded the words of early judicial decisions that sought to protect Indian legal claims. Surely this harsh historical reality does not excuse judges today who play fast and loose with precedents and with purportedly logical constraints. If anything, past judicial complicity in outrages perpetrated against Native Americans ought to make today's judges particularly sensitive to historical claims. Yet Abstract History, Cumulative History, and Implicit History all seem to flow together in the three decisions we considered. At their confluence, history is, in fact, not relevant at all.

\section{CONCLUSION}

The careless, perhaps even cynical, manipulation of foundational words and past deeds in these three contemporary opinions contrasts starkly with the power of words and great weight of the past as they are

45 This is standard, boiler-plate language that stretches back for more than a century. Thomas quotes Yakima v. Yakima Indian Nation, 112 S. Ct. 683, 693 (1992), quoting older decisions for the idea. Other citations he omitted would have emphasized both the longevity and the respectability of the idea that in construing statutes and treaties "the language used in treaties with the Indians shall never be construed to their prejudice", as Chief Justice John Marshall put it in the famous decision, Worcester v. Georgia, 31 U.S. 515, 582 (1832).

47 Cherokee Nation v. Georgia, 30 U.S. (5 Pet.) 1, 17 (1831). 
articulated in Native American cultures. That tradition emphasizes "the rich complexity of meanings" 48 in traditional American Indian narratives. Karl Kroeber and other authors convincingly make the case that "[i]t is our scholarship, not Indian literature, which is 'primitive' or undeveloped". 49

To understand the tremendous and tragic gap exemplified in these judicial opinions, it is hardly necessary to develop expertise in American Indian literary art, for example, or in anthropology. Moreover, one surely must be wary of the familiar tendency to romanticize some mythic Noble Savage. Yet this brief legal review of undramatic recent decisions concerning Native Americans emphasizes how lacking in nuance indeed how primitive - contemporary judicial approaches to history, meaning and accuracy actually are.

All these judges claim to rely on history, yet betray a failure to remember. Whether tragedy or farce, the different judicial invocations of history demonstrate law-office history at its worst. The judges not only fail to comprehend the meaning of history. They are also strikingly inept in their consideration of the history of meaning. The lack of understanding and the denigration of the need for mutual translation reflected in these decisions demonstrates that our mainstream legal culture has gleaned little from the nation's long history of partial justice toward Native Americans. If we have learned anything from our past mistakes, here it seems to be an urge to repeat them exactly.

It may be that to rely on history in the cause of violence is a gruesome curse. As the Nobel Prize-winning poet Joseph Brodsky said about the current bloodshed in the Balkans, "Whenever one pulls the trigger in order to rectify history's mistakes, one lies. For history makes no mistakes, since it has no purpose". ${ }^{50}$ But it is radically different when we consider history in the context of the legitimized force - and the legitimating functions - of remedies that judges have the power either to impose or to reject. Judges ought to be held to a higher standard than soldiers in the intertwined matters of history and justice.

Indeed, history should be a constant concern for those who judge. To abuse or ignore history is to forget a crucial link. Finding out what happened and why should be crucially relevant when judges consider

Traditional Literatures of the American Indian 8 (K. Kroeber ed., 1981). Kroeber and the other authors in this compilation explore the interworking of texture, text, and context within American Indian oral traditions, and they probe the complexity of any translation.

Ibid., 9.

J. Brodsky, "Blood, Lies And the Trigger Of History", N.Y. Times, 4 August 1993, at A19. 
Native American legal claims. Legal amnesia is always unjust. But injustice is compounded - and becomes almost unbearably poignant and powerful - when failures of memory, meaning and history are invoked to brush away the claims of Native Americans. Native Americans as a group have been victimized by past legal machinations more than most people in the United States. No ahistorical antiseptic can camouflage the wound. No judicial cleansing will eliminate the stain. 